\title{
The Influence of Farmers' Entrepreneurship and Organizational Competence on Cacao Productivity
}

\author{
${ }^{1}$ Saban Echdar, ${ }^{2}$ Muhammad Hidayat, ${ }^{3}$ Novita Dwi Maharani Sabban \\ Lecturer \\ Department of Management \\ ${ }^{1,2}$ Sekolah Tinggi Ilmu Ekonomi (STIE) Nobel, Makassar, Indonesia \\ ${ }^{3}$ Sekolah Tinggi Manajemen Informatika dan Komputer, Makassar, Indonesia
}

\begin{abstract}
This study aimed to determine the effect of entrepreneurial competencies, and institutional productivity of farmers on cocoa production at Polewali Mandar, West Sulawesi Province, Indonesia. The sample of 100 cocoa farmers at Polewali Mandar. The study was conducted by survey method through a quantitative approach. The research variables are entrepreneurial competence, institutional farmers, and cocoa productivity. Data analysis using multiple linear regression with the used software SPSS 20 for windows. The study shows that the entrepreneurial competencies and institutional capacities of farmers simultaneously and partially positive and significant impact on the productivity of cocoa. The better the entrepreneurial and institutional competence of farmers, the cocoa productivity will increase.
\end{abstract}

\section{Index Terms - Competence entrepreneurial, Institutional Farmers, Cocoa Productivity}

\section{INTRODUCTION}

Cocoa is a crop that is mostly cultivated by farmers in lowland tropical areas, including parts of Latin America, West Africa, and Indonesia [1]. West Sulawesi Province is one of the regions in Indonesia with high cocoa producing. Most of the inhabitants are plantation livelihoods with the main product being cocoa. Even this plantation activity absorbs more than $50 \%$ workforce in West Sulawesi Province. However, cocoa production decreases or productivity only reaches $0.4-0.6$ million tons / hectare. The productivity value is very small compared to the productivity potential should reach 1-1.5 million tons / hectare.

The decreasing amount of cacao is a result of old age plants, pests, disease and low quality [2]. The low quality of cacao production due to farmers does not make plant maintenance and maintenance efforts. Cacao plants that are not well maintained and with age more than 25 years lead to low productivity. Also, fertilization is also not done correctly according to the rules due to lack of capital of farmers[3].

On the other hand, the institutional farmers are also not functioning correctly. The problem of cocoa farmers is not only production and post-harvest problems. The farmer has also the institutional issues. Farmer institutions or organizations in rural areas are the communication media and internal strength of the community. This organization can become a discussion space in overcoming problems in cacao cultivation. However, the institutionalization of cacao plantations has not been optimal. Therefore, the impact on the productivity of cocoa. Severally another problem is the institutional organization of farmers as farmers are not working correctly, insight and knowledge of farmers towards entrepreneurship remain low, farm management remains piecemeal, resulting in low productivity of the farm.

Entrepreneurial competencies needed to improve the quality and productivity of cocoa, because it is a manifestation of behavior in planning a series of activities to achieve the target. Competence refers to the ability of farmers, in general, to run a farm or do the tasks and functions of the job competently, from the process of planting, maintenance, harvesting, to the marketing of their products. It is in accordance opinions [4] that the entrepreneurial competence is functional skills needed to perform tasks on a job according to the standards in the set. Farmers who are competent to become manager of his farming business in performing such tasks as a planned farm, when the time is right planting, harvesting, marketing results, capital and control their farm.

Problems of farmers and farmer institutions in Indonesia is the lack of insight and knowledge of farmers on aspects of production and marketing network, not all farmers involved in agri-business, and institutional farmers as the primary organization not functioning optimally. Furthermore, the weak bargaining position of farmers caused farmers often lack access to markets, market information, and inadequate capital. To overcome this problem the farmer should gather strength in farmer institutions that can channel their aspirations, the farmer-controlled themselves, and farmers should be subject to the process [4].

Based on the results of observations in West Sulawesi Province, there have not been entrepreneurial and institutional linkages of farmers. Furthermore, there was has been no government effort to link these two variables to increase the productivity of cocoa. In connection with farmer institutions, no studies related to the productivity of cocoa, so this study was conducted to examine the effect of entrepreneurial competencies with indicators of knowledge, skills, and attitudes, institutional farmers indicators organizational tasks, as well as human resources and services on the productivity of cocoa in West Sulawesi.

\section{RESEARCH METHODS}

This type of research is a survey with quantitative approach. This study was conducted from April to July 2016 in Polewali Mandar West Sulawesi Province. The populations in this research were all farmers in Polewali Mandar, West Sulawesi Province, Indonesia. Sample selection by the cluster system based on the characteristics of the people in each region.Data collected through 
interviews, questionnaires, and documentation. Analysis of data using multiple linear regression analysis, which previously tested the validity and reliability with the help of the Software program SPSS 20 for windows.

\section{RESULT AND DISCUSSION}

\section{Characteristic Respondent}

The typical respondent includes local origin, education level, cocoa farming experience, access to information and access to capital.

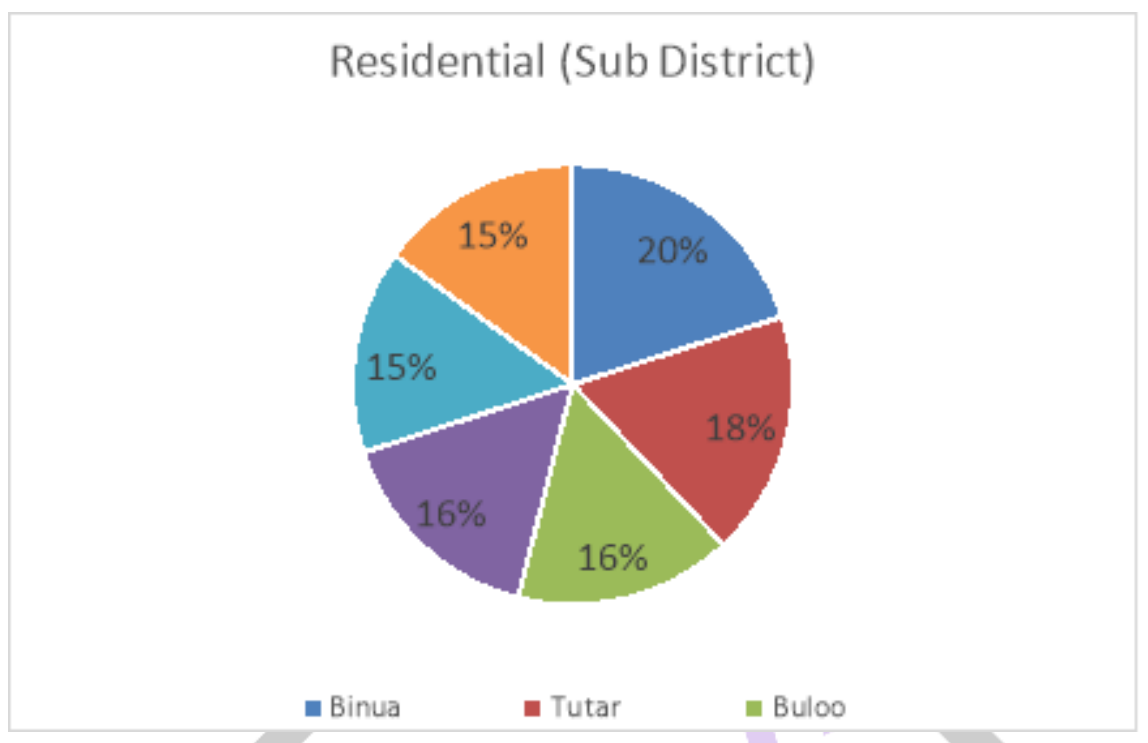

Fig 1: The Distribution of Residential Respondent

Figure 1 describes that respondents come from various sub-districts in Polewali Mandar. There were 15-20\% respondents represent each sub-district. With proper distribution of respondents, the results of research on the characteristics of cacao farmers can be represented. The picture of farmers in all research areas is also relatively similar based on the socio-economic condition.

Figure 2 shows the educational level of respondents. Most of the respondents have secondary school education background (46\%), and only $6 \%$ have an undergraduate education. Educational backgrounds indicate farmers' ability to access information and communicate well with their surroundings.

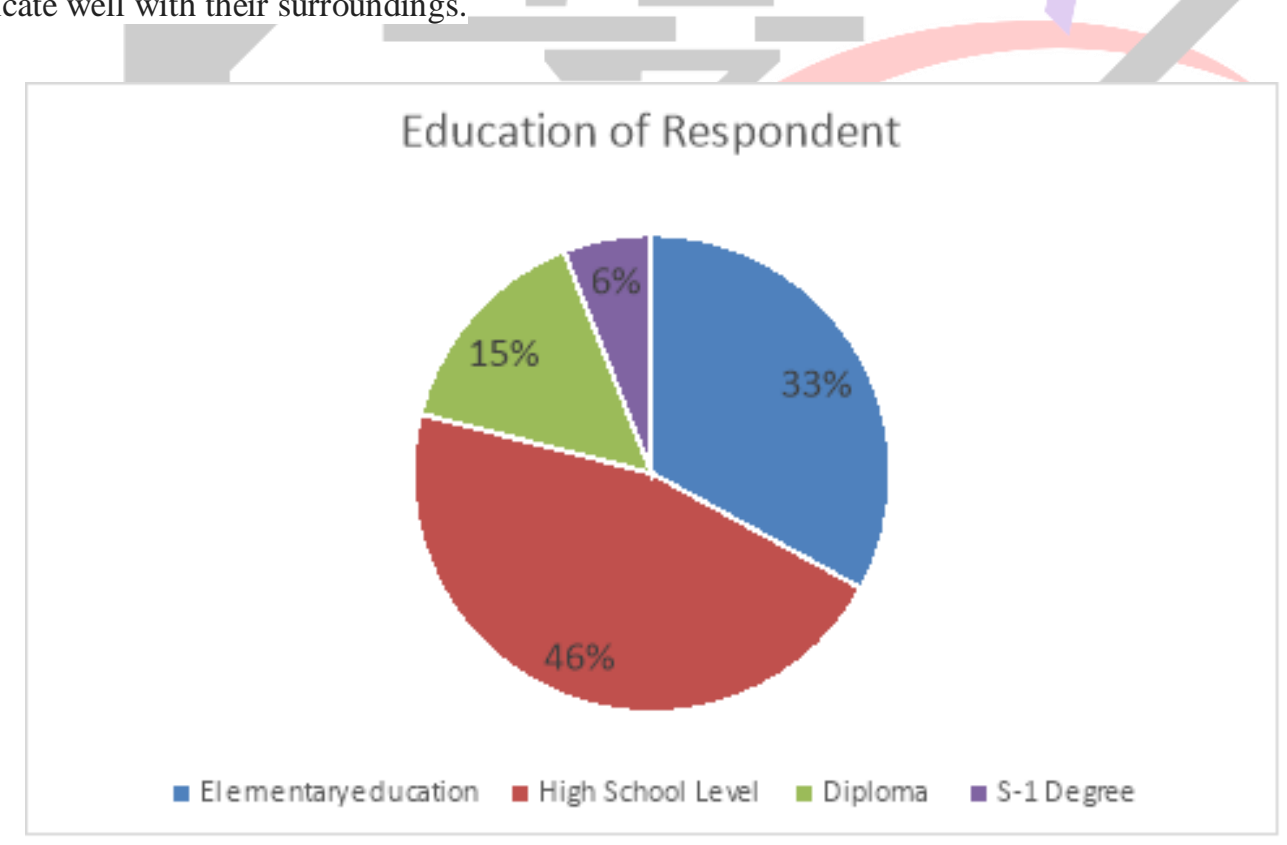

Fig 2. The Educational Respondent

The farming experience shows the length of farmers doing cacao farming. The more farming activity, the more innovation that has been done by a farmer in solving the problem. 


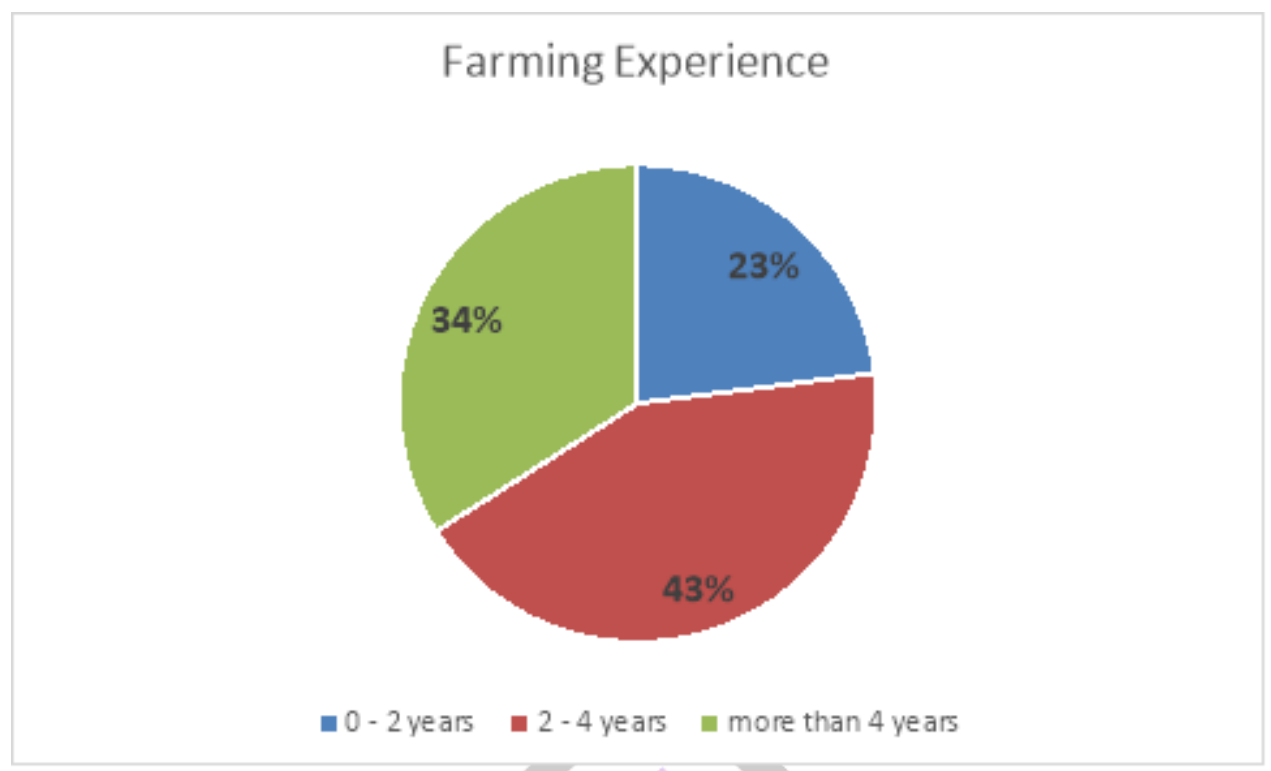

Fig 3. The Farming Experience of Respondent

Figure 3 shows that there are $43 \%$ of farmers who work as cocoa farmers between 2 years - 4 years. Also, there are $23 \%$ of farmers who have not had a cocoa farming business for more than two years. In general, cocoa farmers who start farming in the last two years spend more time in the maintenance of the garden. This is due to the age of cacao less than a year; the plant requires intensive fertilization.

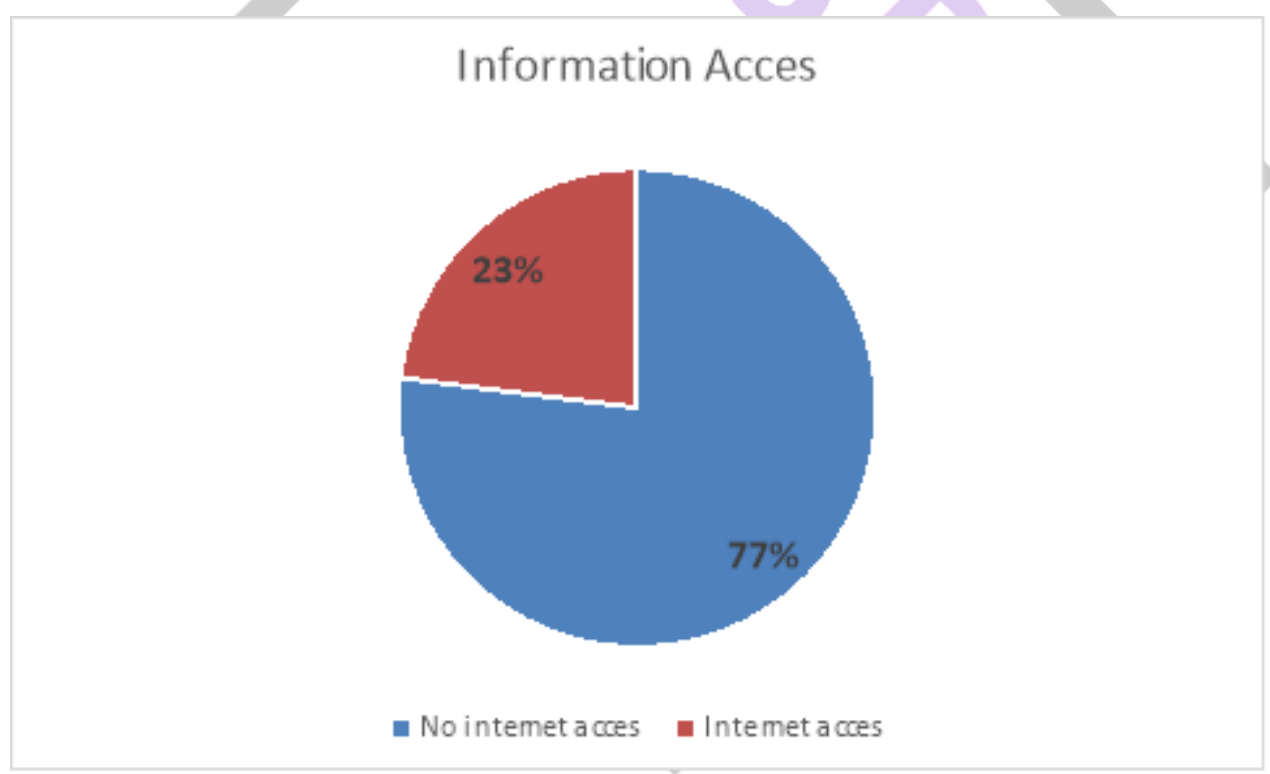

Fig 4. The Information access of Respondent

Figure 4 shows the ability of the farmer to access the information. There was $77 \%$ respondent have not access information by technology. It is a condition caused the difficulties for farmers to improve their ability in cacao cultivation.

Also, farmers must also be supported with venture capital besides knowledge and the farming experience. This capital deals with the cost of purchasing seeds, fertilizers, pesticides, and labor. Figure 5 shows farmers' ability to access capital. 


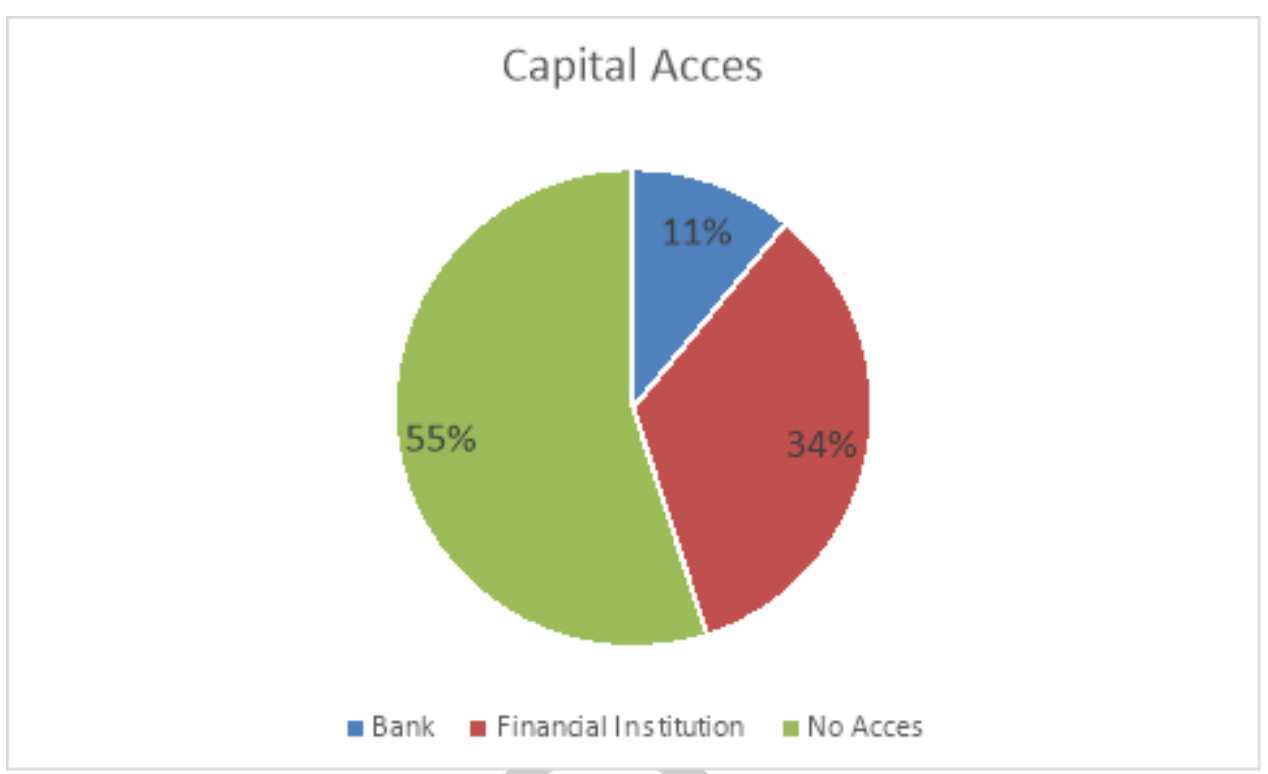

Fig 5. The Information access of Respondent

Figure 5 describes that most respondents did not get the capital loan. Percentage of respondents who received capital from a financial institution as much as $34 \%$ and only $11 \%$ of respondents who received loan assistance from banks.

\section{The Correlation of entrepreneurial competence and institutional influence}

The entrepreneurial competence of respondents is measured by respondents' answers on various indicators. Entrepreneurial competence indicator is three that is farmer innovation, market access ability, and production quality improvement ability. Based on the results of respondents' answers to entrepreneurial competence variables, then obtained a picture that farmers have the low entrepreneurial ability. It is characterized by a farming activity that never changes and is only based on the parents' diving.

The second variable was institutional influence characterized by involvement in farmer institutions and the role of institutions in marketing. The role of institutions in the cultivation of farmers in the low category. The farmers' institutions have not been optimally caused by the lack of participation of farmers to strengthen the institution.

Based on the results of multiple regression analysis known that the analysis of entrepreneurial competence and institutional influence on the productivity of cocoa farmers obtained: $\mathrm{Y}=156260+6.782 \mathrm{X} 1+6.314 \mathrm{X} 2$. It means that if the entrepreneurial and institutional competence of farmers together is increased, then the productivity of cocoa increased. It shows that the entrepreneurial and institutional competence of farmers simultaneously affects the productivity of cocoa.

Based on the coefficient obtained the R-Square value of 0.317 means that the influence of entrepreneurial and institutional competence on the productivity of farmers in Polewali $31.7 \%$. This suggested that other factors affect the productivity of farmers amounted to $68.3 \%$, which is not included in this research model. It is according the last research [5], that the individual characteristics of the most dominant influence are the training and experience of trying. The nature of entrepreneurship that stands out are the motivation, opportunity, and confidence, the ability of the most significant effort is an indicator of raw materials, access to markets and capital.

Based on test results obtained F sig value $0,000<0,05$. It means the entrepreneurial and institutional competence of farmers positive and significant impact on the productivity of cocoa simultaneously. Improved institutional quality cocoa farmers will increase productivity, and vice versa. It because the institutional functioning of the farmers will give farmers the opportunity to get help farmer development program of the government. The existence of institutions for farmers has become a necessity to improve their quality of life, dignity, and status. Institutional farmers should place as a means to realize the hopes, desires, and fulfilling the needs of farmers [6].

The institutional independence peasant farmers will produce so that it can adequately perform product. The autonomy includes: (a) the independence of the material, which can make optimum use of the natural resources they have without having to wait to help others. (b) the independence of intellectual that can criticize and express opinions without overshadowed by fear or pressure other parties. (c) the independence of coaching, which has apatites to develop themselves through the learning process without depending on others; and (d) interdependence, meaning that in carrying out its activities there will always be another man depend on the others in the community as a social system [7].

Based on t-test coefficient influence entrepreneurial competencies and institutional capacities of farmers partially on the productivity of cocoa farmers is seen that entrepreneurial competence with a significance value of $0.027<0.05$. It means that entrepreneurial competence partially positive and significant impact on the productivity of cocoa farmers. Institutional of farmers with a significance value of $0.029<0.05$. It means that farmers institutional partially positive and significant impact on the productivity of cocoa farmers. 
Entrepreneurial competence and significant positive effect partially on cocoa productivity, so an increase in farmers' entrepreneurial competence will increase cocoa productivity, and vice versa. For entrepreneurial competencies are capabilities farmers in land preparation, planting, maintenance, harvesting and post-harvest cocoa. Farmers with good entrepreneurial competence will produce better cocoa productivity because it is a manifestation of behavior to plan activities to achieve the target. This study is in line with the opinion of [8] that farmers should be able to become competent, skilled farm managers to perform their tasks planned farm when to plant, harvest, marketing results, seeking capital, control the farming operation.

Therefore, building institutional and entrepreneurial competencies of integrated and sustainable farmers considered significant. Stakeholders must make efforts, particularly local governments to optimize the function of the help field workers. For example, to increase the capacity of the field extension can be through a participatory approach. This approach is oriented to the needs of the farmer when counseling, strengthen performance, and extension institutions, so that relief activities to improve the entrepreneurial and institutional competence of farmers can perform well, and were directed to increase cocoa production in the province of Polewali Mandar, West Sulawesi.

\section{Conclusion}

Entrepreneurial competence and institutional farmers simultaneously or partially positive and significant impact on the productivity of cocoa. It shows the magnitude of the contribution of entrepreneurial competence and institutional productivity of farmers on cocoa. However, other factors affect the productivity of cocoa in Polewali Mandar West Sulawesi which is not included in this research model, among others: training, quality of cacao seeds, soil fertility and others.

\section{REFERENCES}

[1] M. Franzen and M. B. Mulder, "Ecological, economic and social perspectives on cocoa production worldwide," Biodivers. Conserv., vol. 16, no. 13, pp. 3835-3849, 2007.

[2] J. Neilson* "Global markets, farmers and the state: sustaining profits in the Indonesian cocoa sector," Bull. Indonesia. Econ. Stud., vol. 43, no. 2, pp. 227-250, 2007.

[3] R. Rubiyo and S. Siswanto, "Peningkatan Produksi dan Pengembangan Kakao (Theobroma cacao L.) di Indonesia," J. Tanam. Ind. dan Penyegar, vol. 3, no. 1, pp. 33-48, 2012.

[4] S. L. Morgan, T. Marsden, M. Miele, and A. Morley, "Agricultural multifunctionality and farmers' entrepreneurial skills: A study of Tuscan and Welsh farmers," J. Rural Stud., vol. 26, no. 2, pp. 116-129, 2010.

[5] D. Choudhary, M. S. Kunwar, and G. Rasul, "From Farmers to Entrepreneurs - Strengthening Malta Orange Value Chains Through Institutional Development in Uttarakhand, India," Mt. Res. Dev., vol. 35, no. 1, pp. 4-15, 2015.

[6] S. Abdelhak, J. Sulaiman, S. Mohd, and A. Azman, "The role of institutions in alleviating the vulnera-bility of farmers to poverty in Malaysia: a longitudinal study," Kaji. Malaysia J. Malaysian Stud., vol. 33, 2015.

[7] Y. Hayami and T. Kawagoe, The agrarian origins of commerce and industry: a study of peasant marketing in Indonesia. Springer, 2016.

[8] P. L. Nuthall, Farm Business Management: The Fundamentals of Good Practice. CABI, 2016. 